УДК 378.1.- 057

DOI:

Юлія Колісник-Гуменюк, кандидат педагогічних наук, старший викладач кафедри загальнотехнічних дисциплін і охорони праці відокремленого структурного підрозділу

“Львівський навчально-науковий иентр професійно-технічної освіти” Національного педагогічного університету імені М.П. Драгоманова, м. Київ

\title{
ФЕНОМЕНОЛОГІЧНИЙ ТА СИСТЕМНИЙ НАУКОВІ ПІДХОДИ У КОНТЕКСТІ ПІДГОТОВКИ ВИКЛАДАЧІВ ПРОФЕСІЙНО-ХУДОЖНІХ ДИСЦИПЛІН
}

Підготовка сучасного викладача професійно-художніх дисциплін зорієнтована на формування професійних компетентностей, потребує чітко визначених освітніх цілей $i$ мотивів, організації та проектування психолого-педагогічних умов навчального процесу, спрямованого на фахівия з сучасним типом професійного мислення, здатного до ефективного професійного саморозвитку та самореалізації. Конкурениія яка існуе на сучасному ринку праці, зумовлює потребу формування професійно орієнтованих теоретичних $і$ практичних знань $i$ вмінь майбутніх фахівців, усвідомлення ними сочіально-економічних змін на ринку праџі, адекватного сприйняття цілей $і$ мотивів професійної діяльності в художній царині та сучасних освітніх технологій.

Удосконалення професійної підготовки майбутніх викладачів професійно-художніх дисииплін передбачає врахування низки загальнонаукових і психолого-педагогічних підходів серед яких ми виокремлюємо: феноменологічний та системний.

Ключові слова: вища освіта; фахівещь; художня освіта; художній профіль; феноменологічний підхід; системний підхід.

Jim. 14.

Yuliya Kolisnyk-Humenyuk, Ph.D.(Pedagogy), Senior Lecturer of the General Technical Disciplines and Labor Protection Department of Separate Structural Unit "Lviv Educational and Scientific Center of Vocational Education" National Mykhaylo Drahomanov Pedagogical University

\section{PHENOMENOLOGICAL AND SYSTEMIC SCIENTIFIC APPROACHES IN THE CONTEXT OF TRAINING OF TEACHERS OF PROFESSIONAL AND ARTISTIC DISCIPLINES}

The training of a modern teacher of professional-artistic disciplines is oriented on the formation of professional competences, requires clearly defined educational goals and motives, organization and design of the psychological and pedagogical conditions of the educational process aimed at a specialist with a modern type of professional thinking capable of effective professional self-development and self-realization. The competition existing in the modern labor market necessitates the formation of professionally oriented theoretical and practical knowledge and skills of future specialists, their awareness of socio-economic changes in the labor market, adequate perception of the goals and motives of professional activity in the artistic realm and modern educational technologies.

The instructor must consciously keep up with the present. Understanding and generalization of conceptual and methodological ideas of scientists convinces that vocational and pedagogical training of teachers of professionalartistic disciplines is a creative, non-linear process, which requires the use of poly-approaches, polyparadigms, and polymethodologies.

Improving the professional training of future teachers of professional and artistic disciplines involves taking into account a number of general scientific and psychological and pedagogical approaches among which we distinguish: phenomenological and systemic.

It should be noted that the considered scientific and methodological approaches give a new role to the teacher, turning it into the organizer of cognitive activity of students, and students - in active subjects of cognition and self-development. The realization of the tasks of training teachers of professional and artistic disciplines depends on a number of factors: the level of pedagogical education in the institution, the experience of basic and postgraduate pedagogical education, a defined strategy of vocational and pedagogical training of pedagogical staff, etc. Nowadays there is a transition from the educational ideal, which sets the benchmark for the formation and development of an individual that is capable of life-long education, self-education and self-organization in accordance with social needs. The main attributes of such personality are non-standard thinking, creativity, openness, ability to 


\section{ФЕНОМЕНОЛОГІЧНИЙТАСИСТЕМНИЙНАУКОВІПЦХОДИ У КОНТЕКСТІПДГОТОВКИ ВИКЛАДАЧІВ ПРОФЕСІЙНО-ХУДОЖНІХДИСЦИПЛІН}

make decisions on their own, constant movement towards self-perfection, creative activity, ability to generate new ideas.

Keywords: higher education; a specialist; artistic education; artistic profile; phenomenological approach; system approach.

П

остановка проблеми. Методологія - це концептуальний виклад мети, змісту, методів дослідження, які забезпечують отримання максимально об’єктивної, точної, систематизованої інформації про процеси та явища. В освіті, як відомо, використовуються різноманітні методи навчання: наочні, словесні, практичні, пошукові, репродуктивні, методи стимулювання та мотивації навчальної діяльності, методи контролю знань; їх ефективність зростає завдяки використанню навчально-пізнавальних джерел, періодичних видань, Інтернету. Однак спостереження показують, що в реальній практиці, в процесі навчання студенти (майбутні педагоги) знайомляться 3 методологічними знаннями стихійно, несвідомо. Це пов'язано з тим, що самі викладачі недостатньо володіють методологічною культурою. Також тим, що методологічним знанням приділяють мало уваги. Більшість викладачів помилково вважає, що методологія це галузь науки, яка занадто далека від їхніх потреб, тому в навчальному процесі у 3ВО переважає суто інформативний підхід, студенти орієнтуються лише на засвоєння відповідного обсягу знання й оволодіння обмеженою кількістю практичних навичок. Натомість один 3 найбільших теоретиків педагогіки I.-Ф. Гербарт писав: "Ніде так не потрібні широкі філософські погляди, основані на загальних ідеях, як у педагогіці, де повсякденна робота та індивідуальний досвід сильно сковують кругозір вихователя" [4, 99].

Мета статті полягає в огляді та аналізі загальнонаукових i психолого-педагогічних підходів, які допоможуть удосконалити професійну підготовку майбутніх викладачів професійнохудожніх дисциплін, серед яких ми виокремлюємо: феноменологічний та системний.

Виклад основного матеріалу дослідження. Передусім у контексті підготовки викладачів професійно-художніх дисциплін звернемося до феноменологічного підходу засновником якого став німецький філософ Е. Гуссерль (1859 - 1938) у ХX ст. Феноменологічний підхід $є$ філософською теорією, що має на меті виявити базові структури суб'єктивного досвіду, основоположні духовні інтенції та особистісні смисли, які спрямовують поведінку індивіда. Термін “феноменологія” нині найчастіше застосовують, представники екзистенційно-гуманістичної парадигми, які найбільше уваги приділяють вивченню особистості як єдиного інтегрованого цілого, досліджуючи суб'єктивне світосприйняття.

Феноменологічний підхід відкриває можливість піднятися у самопізнанні над власними знаннями, порівняти їх з іншими знаннями, прийти до певної думки, стати об'єктом споглядання, здійснити рефлексію набутих знань, власних думок, почуттів, педагогічного, зокрема художньопедагогічного досвіду. Усвідомлюючи власні дії та їх мотивацію, індивід здатен замінювати рівень своїх професійних якостей.

Феноменологія торкається також і рефлексів щодо культурологічної проблематики, походження культури, побутування культурних явищ (феноменів). Е. Гуссерль закликав: “назад, до самих предметів!". На його думку, предмети самі по собі розкривають свій зміст без відсилання до природних або створених людиною зв'язків 3 іншими предметами. Смисловий зв'язок реалізується в потоці феноменів, що не містять у собі різниці між буттям і явищем. Феномен, за Гуссерлем - це ідеальна сутність, яка має безпосередню достовірність, i пізнати їі можливо тільки інтуїтивно. Феноменологічний напрям розкриває буття певних явищ культури, осягає сутність явища в образі, виявляє інтерес до форми як творчого начала реальності.

В. Летуновский стверджує, що в основі феноменологічного підходу лежить розуміння унікальності існування людини у світі й унікальності їі власного світу. Феноменологія розглядає екзистенцію людини, висвітлюючи феномени, що належать іiі індивідуальному світові [7]. Цей підхід розкриває значення суб'єктивного досвіду як основного вимірника сутності людини. Відбувається відмова від ідеалізації, догматизму, упередженості під час аналізу й опису наукових і педагогічних поглядів особистості [10, 14].

На думку Е. Фінка, основним феноменом людського існування $є$ саморозуміння людиною себе, самоінтерпретація людиною власного життя. Вирішальними феноменами людського життя є смерть, праця, страх, любов, панування, гра. Будь-який феномен людського існування припускає такі виміри, у яких виховання й освіта здійснюють свої функції смислополягання й смислоздійснення. Вони й формують окремі області виховання й освіти, сприяють ідентифікації людиною певних проблем життя, істотних для педагогічної й освітньої діяльності. 


\section{ФЕНОМЕНОЛОГЧНИЙТАСИСТЕМНИЙНАУКОВІПДХОДИ У КОНТЕКСТІПДГОТОВКИ ВИКЛАДАЧІВ ПРОФЕСІЙНО-ХУДОЖНІХ ДИСЦИПЛІН}

Один із основоположників феноменологічного підходу Н. Смарт $[14,56]$ наголошує, що викладач сучасності, передусім має “проходити тест на відкритість”, він повинен бути гуманістом у широкому розумінні цього слова, ставитися до предмета з творчим підходом і подавати матеріал зі зверненням до особистого досвіду студентів, розкривати в них почуття людяності, толерантності, гідності тощо.

Стосовно художньо-педагогічної підготовки завдання феноменологічного підходу полягає у розвитку відчуття “сутності” та “природи” мистецтва, ставить собі за ціль, виховувати подібний тип чуттєвості, щоб розвинути глибинне розуміння і на основі цього розвинути багато інших моральних якостей [13]. Необхідно розвивати почуття, які можна назвати співпереживання творчої людини, спроба відчути переживання та зрозуміти будь-яку форму проявлення роботи митця. Це можливо, лише тоді, коли викладач і студенти мають змогу поставити себе на місце іншої людини, відсторонитися від своїх особистих звичних уявлень і сконцентруватися на тому, що відчуває інша особистість. Таким чином вони зможуть наблизитись до глибинного розуміння та сприйняття твору $[12,26]$. Знайомлячи студентів iз художніми творами, складно сприяти отриманню широкого розуміння всього спектру окремого мистецтва, тому викладачі повинні намагатися розвивати у студентів вміння, не лише просто описати картину, а намагатися зрозуміти, дізнатися та усвідомити іiі суть.

Системний підхід є найбільш поширеним у науці, та зокрема педагогіці, він базується на теорії систем, що зумовлює походження, функціонування та розвиток систем різної природи. Завданням системного підходу в розроблені методів дослідження та конструювання складних за організацією об'єктів як систем.

I. Блауберг висував основні положення системного підходу через конкретні визначення понять цілого, цілісності, системи і встановлення взаємозалежності між ними. Ціле (whole, das Ganze, le tout) - конкретний об'єкт, що володіє інтегративними (“емерджентними”) властивостями. Цілісність (wholeness, die Ganzeit, la integrite) уявлення про повноту явища і разом з тим про сутність інтеграції, процесів новоутворення, структурних рівнів, ієрархічної організації процесів i явищ які існують завжди у філософському i науковому пізнанні. Це - фон, на якому розгортається пізнання цілісних об'єктів, орієнтир пізнавальної діяльності. Цю функцію поняття цілісності виконує в силу того, що воно має своєрідну структуру яка включає в себе не тільки актуальне, але й потенційне знання. Система (system, das System, systeme) - поняття, яке служить для відтворення в знанні цілісного об'єкта за допомогою специфічних принципів, визначених понятійних і формальних засобів; як правило, це відтворення здійснюється з певною практичною спрямованістю [3, 244]. Поняття “система" визначається як множина взаємопов'язаних елементів, що утворюють цілісність, стійку єдність із середовищем, якій притаманні інтегральні властивості і закономірності $[8,22]$. В. Безпалько під системою розуміє будь-який процес, що відбувається за конкретних умов і в сукупності з цими умовами $[2,25]$. Система навчання - сукупність принципів, що є основою для будь-якого навчання $[9,7]$.

Системний підхід у педагогіці спрямований на розкриття цілісності педагогічних об'єктів, виявлення в них різноманітних типів зв'язків і зведення їх в єдину картину. У вузькому значенні системність і систематичність у навчанні передбачає засвоєння знань, навичок і вмінь у певному логічному зв'язку, коли провідне значення мають істотні риси об'єкта вивчення i коли воно, становить собою цілісне утворення, систему [5, 305].

Проблеми застосування можливостей системного підходу до вивчення педагогічних явищ і процесів досліджували: М. Алексєєв, В. Афанасьєв, Л. фон Берталанфі, І. Блауберг, А. Богданов, Л. Гордін, М. Данилов, П. Друкер, Т. Ільїна, В. Загвязінський, П. Ерднієв, Ф. Корольов, Д. Логвинов, О. Любарська, В. Максименко, Н. Мойсєєв, П. Олійник, Є. Павлютенков, О. Пєхота, I. П'ятницькаПозднякова, В. Рубахін, А. Кіктенко, А. Нісімчук, В. Садовський, Г. Саймон, С. Сисоєва, О. Сохор, Ю. Сурмін, А. Чандлер, Ю. Щербань, О. Щолокова, Е. Юдін та ін.

У концепції Т. Ільїної зустрічаємо поняття “системно-структурний підхід”. Сутність його полягає в тому, що “спочатку проводиться структурний аналіз, а потім відбувається системний розгляд об'єкта" $[6,7]$. Під системою вона розуміє “множину взаємопов'язаних елементів, об’єднаних загальною метою функціонування та єдністю керування, що виступають у взаємодії із середовищем як цілісна єдність". Серед елементів системи навчання вчена виділяє: навчальний матеріал, учитель, учні, навчальні посібники та технічні засоби навчання. Ю. Бабанський вважає, що навчальний процес можна розглядати двояко з точки зору складу 


\section{ФЕНОМЕНОЛОПЧНИЙ ТАСИСТЕМНИЙНАУКОВІПДХОДИ У КОНТЕКСТІПДГОТОВКИ ВИКЛАДАЧІВ ПРОФЕСІЙНО-ХУДОЖНІХ ДИСЦИПЛІН}

системи, в якій функціонує процес, і складу самого процесу [1, 37].

Універсальність системного підходу сприяє використанню його у дослідженнях різних проблем урізних сферах науки і практики. Цінність цього підходу для методології науки полягає у формуванні загальносистемних законів (співвідношення цілого та частини, емерджентності, взаємозв'язку структури i функції, функціональної цілісності системи, простоти і складності системи, обмеження різноманітності системи, закритих і відкритих систем), що зумовлюють залежність між окремими сторонами і властивостями систем.

Нині системний підхід використовується для створення моделі підготовки майбутніх викладачів до інноваційної професійної діяльності та критеріїв їх готовності до такого виду діяльності. За системного підходу підготовка майбутніх викладачів до інноваційної професійної діяльності розглядається як сукупність взаємопов'язаних компонентів: мета, суб'єкти педагогічного процесу, зміст, форми, методи і засоби підготовки майбутніх викладачів.

Наполягаючи на необхідності використання в процесі навчання системного підходу для вивчення різноманітних мистецьких педагогічних явищ і О. Щолокова зазначає, що “основним завданням системного підходу є озброєння студентів не лише фактичними теоретичними знаннями, а й методологічними, тобто знаннями про найважливіші елементи знань і структурні зв'язки між ними" $[11,13]$.

Висновок. Зазначимо, що розглянуті науковометодологічні підходи відводять нову роль викладачу, перетворюючи його в організатора пізнавальної діяльності студентів, а студентів - у активних суб'єктів пізнання та саморозвитку. Реалізація завдань підготовки викладачів професійно-художніх дисциплін залежить від низки чинників: рівня педагогічної освіти в закладі, досвіду базової та післядипломної педагогічної освіти, визначеної стратегії професійнопедагогічної підготовки педагогічних кадрів тощо. Нині відбувається перехід від освітнього ідеалу, що задає орієнтир на формування та розвиток особистості, яка здатна до освіти протягом життя, самоосвіти і самоорганізації відповідно до суспільних потреб. Основними атрибутами такої особистості $€$ нестандартне мислення, креативність, відкритість, здатність самостійно приймати рішення, постійний рух до самовдосконалення, творча діяльність, здатність генерувати нові ідеї.

Головним питанням сьогодення в системі

вищої професійної освіти є опанування студентами умінь і навичок саморозвитку особистості, що значною мірою досягається шляхом впровадження інновацій в організації процесу навчання. Використання новітніх технологій у навчальному процесі дозволяє викладачам реалізувати свої педагогічні ідеї, а студентам можливість самостійно обирати освітню послідовність, темп вивчення та методи контролю знань. Завдяки цьому в суб'єктів освітнього процесу виробляється індивідуальний стиль діяльності, культури самовизначення, відбувається особистісний і професійний розвиток.

Отже, враховуючи провідні наукові підходи до професійно-педагогічної освіти майбутніх викладачів професійно-художніх дисциплін, вважаємо, що актуальним у модернізації роботи закладів вищої освіти, які здійснюють їхнє навчання, є підготовка студентів до інноваційної педагогічної діяльності з урахуванням вимог феноменологічного та системного методологічних підходів.

\section{ЛІТЕРАТУРА}

1.Бабанский Ю.К. Оптимизация процесса обучения. - М., 1977. - 138 с.

2. Безпалько В. П. Основы теории педагогических систем. - Воронеж: Изд-во ВГУ, 1977. - 204 с.

3. Блауберг И.В. Проблема целостности и системный подход/ Блауберг И.В. - М.: Эдиториал УРСС, 1997. - 450 с.

4. Гербарт И.Ф. Избранные педагогические сочинения - М.: Учпедгиз, 1940. - Т.1. - 292 с.

5. Гончаренко С. У. Український педагогічний словник. / С. У. Гончаренко. - К. : Либідь, 1997. $374 \mathrm{c}$.

6. Ильина Т.А. Структурно-системний подход к исследованию педагогических явлений // Результаты новых исследований в педагогике. М., 1977. - С. 5-9.

7. Летуновский В. Экзистенциальный анализ. История, теория и методология практики. “ Дисс. канд. психол. н. - М., 2001. - 173 с.

8. П’ятницька-Позднякова I. С.Основи наукових досліджень у вищій школі: Навч. Посібник/ І.С. П'ятницька-Позднякова. - К., 2003. $-116 \mathrm{c}$.

9. Павлютенков С. М. Мистецтво управління школою / С. М. Павлютенков. - Х.: Вид. група “Основа", 2011. - 320 с.

10. Сухомлинська О. В. Історико-педагогічний процес: нові підходи до загальних проблем / О.В. Сухомлинська. - К.: А.П.Н., 2003. - 68 с.

11. Щолокова О. П. Модернізація фахової 


\section{ФЕНОМЕНОЛОПЧНИЙТАСИСТЕМНИЙНАУКОВІПДХОДИ У КОНТЕКСТІПДГОТОВКИ ВИКЛАДАЧІВ ПРОФЕСИЙНО-ХУДОЖНІХ ДИСЦИПЛІН}

мистецької освіти у контексті сучасних гуманістичних ідей / О. П. Щолокова. // Науковий часопис НПУ ім. М. П. Драгоманова. Серія 14. Теорія і методика мистецької освіти: зб. наук. пр. (Матеріали II Міжнародної науково-практичної конференції "Гуманістичні орієнтири мистецької освіти”. - К.: НПУ, 2007. - Вип. 4. - С. 11-14.

12. Grimmit M. What can I do in R.E.? / Michael Grimmit. Great Wakering, Essex: MayhewMcCrimmon. - 1973. - p. 26.

13. Owen Cole W. Religion in the Multi Faith School / W. Owen Cole // Learning for living. - 1972. - Vol. 12, No 2, November. - p. 49.

14. Smart N. Secular Education and the Logic of Religion / Ninian Smart. - London: Humanities Press, 1969. - 108 p. - p. 98.

\section{REFERENCES}

1. Babanskiy, Yu. K. (1977). Optimizatsyia processa obucheniya [Optimization of the training process]. Moscow, 138 p. [in Russian].

2. Bezpalko, V. P. (1977). Osnovy teoriyi pedagogicheskikh system [Basics of the theory of educational systems]. Voronezh, 204 p. [in Russian].

3. Blauberg, I. V. (1997). Problema celostnosti $i$ sistemnyy podhod [Problem of unity and systemic approach]. Moscow, 450 p. [in Russian].

4. Herbart, I. F. (1940). Izbrannyye pedagogicheskiye sochinyeniya [Elected pedagogical works]. Moscow, Vol. 1, 292 p. [in Russian].

5. Honcharenko, S. U. (1997). Ukrayinskyy pedahohichnyy slovnyk [Ukrainian pedagogical dictionary]. Kyiv, 374 p. [in Ukrainian].

6. Ilyina, T. A. (1977). Strukturno-sistemnyy podkhod $k$ issledovaniyu pedagogicheskikh yavlyeniy [Structural-systemic approach to research of pedagogic events]. Results of new researches in pedagogics. Moscow, pp. 5-9. [in Russian].

7. Letunovskyy, V. (2001). Ekzystencyalnyy analiz. Istoriya, teoriya $\mathrm{i}$ metodologoya praktiki [Existencial analysis. History, theory and methodology of practice]. Candidate's thesis. Moscow, 173 p. [in Russian].

8. Pyatnytska-Pozdniakova, I. S. (2003). Osnovy naukovykh doslidzhen $u$ vyshchiy shkoli [Basics of scientifical researches in a High School]. Kyiv, 116 p. [in Ukrainian].

9. Pavlyutenkov, Ye. M. (2011). Mystetstvo upravlinnia shkoloyu [The art of school management]. Kharkiv, 320 p. [in Ukrainian].

10. Sukhomlynska, O. V. (2003). Istorykopedahohichnyy protses: novi pidkhody do zahalnykh problem [Historically-pedagogical process: new approaches for a common problems]. Kyiv, 68 p. [in Ukrainian].

11. Shcholokova, O. P. (2007). Modernizatsiya fakhovoyi mystetskoyi osvity u konteksti suchasnykh humanistycjnykh idey [Modernization of professional artistic education in the context of modern humanistic ideas]. Scientific journal of NPU by M.P. Drahomanov, Book 14. Theory and methodic of artistic education. Kyiv, Vol. 4, pp. 11-14. [in Ukrainian].

12. Grimmit, M. (1973). What can I do in R.E.? Great Wakering, Essex: Mayhew-McCrimmon, p. 26. [in English].

13. Owen Cole W. (1972). Religion in the Multi Faith School. Learning for living, Vol. 12, No 2, p. 49. [in English].

14. Smart, N. (1969). Secular Education and the Logic of Religion. London, Humanities Press, p. 98. [in English].

Стаття надійшла до редакції 24.01.2019

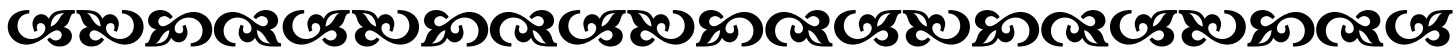

"Мистеитво - вираження найглибиих думок найпростішим способом".

$$
\begin{array}{r}
\text { Альберт Ейнштейн } \\
\text { один з найвизначніших бізиқів ХХ століття }
\end{array}
$$

“Ні мистеитво, ні мудрість не можуть бути досягнуті, яқщо їм не навчитися".

Deмокріт

давньогрещький боілособ

"Недостатньо тільки отримати знання; їх треба застосувати. Недостатньо тільки бажати; треба діяти".

Г̆оганн-Вольббант бон Тете поет, прозаїк, драматург

\section{G58080ल2058080}

